\title{
A Research on the Legal Problems of Trade and Investment Facilitation in GMS
}

\author{
Yue Zhou * \\ International Business School \\ Yunnan University of Finance and Economics \\ Kunming, China \\ 185611009@qq.com
}

\author{
Fangmeng Nie \\ International Business School \\ Yunnan University of Finance and Economics \\ Kunming, China \\ 645578024@qq.com
}

\begin{abstract}
The Lancang - Mekong River is the only international rivers in Asian, the river including six countries Myanmar, Laos, Thailand, Cambodia, Vietnam, and China. At present, under the new situation like the international political multi-polarization, the world economic globalization and regional economic integration, under the new opportunities with China Asean free trade area, it's very important to strengthen and deepen the cooperation within Lancang - Mekong sub-regional. Through the gradually mature of legal mechanism to solve conflicts and disputes, improve the level of sub-regional cooperation between social economy, promote sub-regional trade facilitation process, China should give full play to regional powers in the region's economic development and stable guarantee lead role in the long-term interests of the coastal states.
\end{abstract}

Keywords—GMS; trade; investment; facilitation; laws

\section{INTRODUCTION}

The Greater Mekong Sub-region(GMS), as a geographical concept, comes from a river, the Great Mekong River. It's called Lancang River in China, southward flow through Myanmar, Thailand and other places, known as the Mekong River, so this river was collectively referred to as the Mekong River. It flows through our country and through several countries in Southeast Asia, to connect China and have become the natural bridge of these countries to strengthen the geographical contact. Sub-region refers to some small areas like Yunnan province, Guangxi province in China, sharing the Greater Mekong River is the characteristics of this region [1][2]. The region's economic development and social status are relatively backward due to historical, political and other factors. With the arrival of the new century and modernization, various countries have already begun to carry out a series of economic reform, adjusted their own industrial structure, promoted the opening up of foreign trade, so accelerating economic development and promoting social development has become a common goal of these countries. Because of the strong economic complementarity, foreign trade and investment and cooperation in this region, the potential for future development is endless [3].

The economic cooperation in GMS is of great significance in any area. First of all, these countries are located in the vicinity of a river, played an important role as bridge and channel in China and Southeast Asia. Each country to do a good job can further promote the economic and trade ties and development, and further promote political friendship. Second, forming a unified cooperation mechanism of the sub-regional countries in the local is benefit to further promote the unity and friendship entire between the FTA member countries [4]; Moreover, through solving a variety of legal issues, more mature mechanisms can be directly applied to the free trade area, it can not only save a lot of exploration time, to further promote the construction of China - ASEAN Free Trade Area, but also for a greater range of future East Asia region Cooperation, and to lay a favorable foundation for accelerating the establishment of the ASEAN Free Trade Area [5].

\section{TRADE AND INVESTMENT LEGAL SySTEM STATUS IN GMS-LEGAL DOCUMENT "STRATEGIC FRAMEWORK FOR TRADE AND INVESTMENT FACILITATION"}

GMS countries can communicate with each other in resources. In these countries, the level of development in China and Thailand is relatively better, the other four countries are relatively backward but have great potential, so these places have became a good place for China's investment. There is a huge difference in the level of economic development among regional countries, but it does not affect the mutual exchange and cooperation among them, and the economy exist highly complementarity.

Regional economic cooperation often give priority to the development of trade, GMS also follow this law [6]. At present, GMS trade development is increasingly mature, trade volume is growing, the structure from a single towards a reasonable slowly. The main objective and sign of subregional cooperation is that trade and investment are increasingly facilitated, and sustainable trade must include facilitation. Facilitation, involves many cumbersome matters, trade relations, trade infrastructure, trade system etc., is a process and system.

GMS facilitation is mainly to achieve: the efficiency of administrative services needs to further improve, the transaction costs to be reduced, the transaction time to be reduced, the transaction supporting system to be further improved, the flow of goods and the flow of personnel need to comply with the development of the market. Laws and regulations, documents need to be more transparent, it is best to achieve mutual trade information. The only legal document 
is the Strategic Framework for Trade and Investment Facilitation. Its main contents include [7]:

\section{A. Customs aspect}

Whether trade facilitation is effective or not depends on the implementation of customs measures, optimize the transit system of import and export and trade operators, and keep trade operators and their agencies to know relevant information in time. In the GMS sub-region, the further development of trade between countries is a key objective, and calls for increasing concentration and coordination of customs laws, regulations, systems and documents. Relatively departments have made great efforts to simplify the coordination of the customs system, to unify tariff (using the ASEAN Harmonized Tax Classification System), to implement the valuation agreement" and to solve the complex issues of the principle of preferential treatment of origin. The principle of preference for origin is different from the valuation, and it is not regulated by the WTO level(except for one declaration, included in Annex 2).

\section{B. Trade and Logistics}

Conventionally, GMS cross-border traffic interventions are focused on economic corridor hardware (such as roads, bridges, etc.). The development of these infrastructures has greatly contributed to the opening of trade routes and new investments in sub-regions. At the same time, it provides cross-border traffic regulations and systems related to economic corridors. The GMS countries have ratified the agreement and negotiations on the implementation of the annexes and protocols are already in the final stages. However, to give full play to the role of hardware facilities and simplified border procedures, synchronizing the development of trade logistics departments is necessary, namely service providers.

\section{The flow of business people}

Mainly to encourage the free flow of people, the rapid progress, and to develop a single window program under the economic cooperation strategy (including Cambodia, Laos, Myanmar, Thailand, Vietnam). However, the focus of the program is to encourage tourism from citizens of other countries outside the sub-region, and China has not joined the plan yet. About a GMS country to implement visa-free measures for a number of third-country citizens, some countries in GMS are exempted only in specific areas. Through the further simplicity, convenience, optimization of the visa procedures, the relevant provisions of the protocol will be well followed, business people will automatically flow into other countries.

\section{Inspection and quarantine measures}

There is a large number of universal inspection and quarantine standards, GMS countries should abide by actively. For example, the standards of the International Organization for Animal Health, the International Electro technical Commission standards, as well as the World Health Organization standards. In order to facilitate trade and investment facilitation, GMS countries on the one hand to simplify the quarantine transit requirements, balance international obligations, on the other hand to meet the health requirements, laws and regulations, conformity assessment procedures more transparent.

\section{THE MAIN LEGAL ISSUES AND COUNTERMEASURES} RESEARCH ON THE TRADE AND INVESTMENT FACILITATION OF GMS

The Trade and investment cooperation, as well as trade and investment facilitation in GMS countries, is one of the priority areas for GMS cooperation to reduce or eliminate nontariff measures, in particular to simplify customs procedures, standardize inspection and quarantine standards, and improve laws and regulations transparency, the exchange and sharing of information, further reduce and eliminate trade barriers, improve the investment environment, thereby promoting trade and investment growth, to achieve GMS common development and prosperity. In recent years, China's economy has been developing continuously, the rapid growth of import and export trade has attracted the expansion of foreign investment and foreign investment. The surrounding areas are becoming the key areas for China's development of foreign trade relations. The bilateral trade and investment growth between China and other members of the sub-region also showed a rapid development, a favorable development of trade structure change, and closer economic and trade cooperation, contributing to the development of the GMS. Regional cooperation and its political and economic environment, are needed the protection and control of laws and regulations. The caprice legal and emerging issues in the GMS have affected the expansion and deepening of cooperation. To establish the legal framework, to improve the corresponding system construction, to establish and implement laws and regulations at all levels, and to cooperate with the consultation mechanism between sub-regional governments, it will protect the normal operation of market. From China, the legal issues that need to be studied in this field of cooperation mainly involve the following aspects:

\section{A. About Taxation}

\section{1) On tax barriers}

In order to solve the tax problem between countries, the Chinese government have signed a comprehensive agreement with other countries officially to avoid double taxation and the prevention of tax evasion since September 1983. In recent years, our country has signed tax treaties with respect to income and property to avoid double taxation in most countries and regions in order to protect the taxpayer's rights and interests and avoid double taxation. The Mainland has also signed a double taxation arrangement with Hong Kong and Macao [8]. The 77 agreements and the two arrangements have been put into effect. Most of them include the terms of the mutual consultation procedure for resolving the tax dispute. They have become the solution to the contradiction between the taxpayer's country of residence and the country of origin, and avoid international double taxation of the important legal protection, but because many of our taxpayers do not understand the relevant international tax treaty, encountered in the non-compliance with the tax treaty tax treatment, do not know what channels to maintain their legitimate rights and interests, their legitimate rights and interests often suffered. How to avoid double taxation when investing abroad? Where 
to complain when the offshore job income was repeated? How to do in the outside can not enjoy the tax treaty provided by the preferential policies? These problems will often encounter international tax law barriers in GMS about "going out" investment Enterprises and individuals. Moreover, the issue of taxation is also a matter of continuous cooperation in the process of cooperation among the countries of the sub-region. It needs to keep pace with the times and solve them on different issues.

2) On the Issues of Special preferential tariff arrangements and Non - discriminatory trade principles of WTO

At the meeting of China-ASEAN leaders $(10+1)$ in November 2001, Chinese Premier Zhu Rongji and ASEAN leaders agreed to establish the China-ASEAN Free Trade Area in the next 10 years. This trade area will cover all sub-regional countries and create favorable external conditions for the development of trade and investment in the sub-region. At the meeting, Premier Zhu also announced that China has imposed special preferential tariff arrangements on some of the three least developed countries in Cambodia, Laos and Myanmar, within the framework of the China-ASEAN Free Trade Area. The initiative of the Chinese government can not only promote trade and investment in the sub-region effectively, enhance economic ties, but also can play an active role in achieving the goal of "common prosperity" in sub-regional cooperation.

In July 2005, Chinese Premier Wen Jiabao announced at the opening ceremony of the second meeting of leaders of the Greater Mekong Sub-region Economic Cooperation in Kunming that in order to eliminate trade and investment barriers and promote trade facilitation of sub-regional trade with China-ASEAN Free trade area construction interaction, for the free movement of goods and personnel to create a smooth environment, in order to further promote the economic development of these three countries to achieve regional common prosperity, China decided that since January 1, 2006, unilaterally Laos, Cambodia and Myanmar to expand the scope of preferential tariff products to improve the level of regional trade cooperation.

On December 11, 2005, China, Cambodia and the three countries held a signing ceremony in Kuala Lumpur about "China to Cambodia, Laos, Myanmar to expand the special preferential tariff treatment", China will implement unilateral zero tariff treatment on the part of products exports to China in this three countries from 2006 [9]. According to this exchange, China will implement unilateral zero tariff treatment on Cambodia 83 items, Laos 91 items and Myanmar 87 items from 2006. Special preferential tariff treatment is China's preferential tariff or tax exemption for all or part of the country concerned with a free trade agreement with China.

The principle of non-discriminatory trade is one of the basic legal principles of WTO, which is manifested as "general MFN" and "national treatment". The principle of MFN is that if a member gives another member a preferential treatment, it should "immediately and unconditionally" extend the same preferential treatment to all members to ensure that no member is "discriminatory". Cambodia officially joined the World Trade Organization on October 17, 2004, and in
November 2002, during the Sixth China-ASEAN Leaders' Meeting, China signed an exchange of letters "Cambodia's special preferential tariff treatment with Cambodia" [10] . It was decided that Cambodia was not a member of the WTO when China provided the first batch of preferential tariff treatment for 335 products in Cambodia since January 1, 2004, and after Cambodia joined the WTO on October 17, 2004, China announced that since 2006, Cambodia and other parts of the three countries exported to China's products to implement unilateral zero tariff treatment, in accordance with the requirements of WTO non-discriminatory trade principles, other WTO members also have the same treatment should be given the problem. In particular, after the accession to the WTO, the relevant departments of the Chinese government have publicly stated that a fair and unified tariff rate should be implemented in the customs territory in accordance with the principle of non-discrimination. On the basis of the gradual reduction of the tariff rate, adjusting and clean-up tax relief policy step by step, improving the system about tax dispute complaints and reconsideration, promoting norms, fair, transparent and efficient, and seriously work on the customs duty, and said responsible that "China is a responsible powers, regardless of customs tariffs and management of what happens, will seriously fulfill the commitments made by China, and strictly abide by the WTO rules" [11].

The problem is that China should be forward-looking to apply to non-discrimination against other WTO members before announcing the special preferential tariff treatment of sub-regional economic development in countries with special economic cooperation the principle of trade. Some views regarded that China is based on the "China-ASEAN Comprehensive Economic Cooperation Framework Agreement", "China to Laos, Cambodia and Myanmar to provide special preferential tariff treatment exchange" is an agreement under a Preferential trade agreement "China ASEAN comprehensive economic cooperation framework agreement" [12]. Some other views regarded that China is based on the WTO "authorization clause" that China is in accordance with the provisions of the WTO "authorization clause", in addition to the four least developed countries Cambodia, Myanmar, Laos and Bangladesh implemented the preferential tariff rate in 2005 , the product will also impose a preferential tax rate of zero on some of the 27 least developed countries in Africa to support these countries as soon as possible to develop their economies and get rid of poverty. The WTO "authorization clause" allows members to give developing members better trade benefits than other members. Although the EU believes that this does not mean that the same tariff concession should be applied indiscriminately to all developing members. But these two statements are inaccurate, are unable to completely avoid the WTO nondiscriminatory trade principles of the basic principles in WTO [13].

\section{B. Inspection and quarantine issues}

1) Product testing and certification standards, and mutual recognition

In recent decades, non-tariff measures have become important trade barriers due to declining tariffs and unilateral, regional and multilateral liberalization. Increasingly, 
preferential trade agreements have put product standards as an important type of potential non-tariff barriers. Product standards generally mean promoting important public policy objectives such as environmental protection, consumer safety, food quality, or compatibility between different technical specifications and standards. Product testing and certification standards for the unity of China and ASEAN trade will bring convenience, and can improve the production efficiency and reduce costs directly or indirectly. Therefore, the elimination of double inspection and certification of the cumbersome procedures to shorten the export of goods into each other market time is very important.

\section{2) Proof of origin}

Certificate of origin is proof of the place of production or manufacturing of documents, is the "economic nationality" and "passport" of goods in international trade. FORM-A and China-ASEAN Free Trade Area Preferential Certificate of Origin (FORM-E) are eligible for customs clearance. Enterprises in the export application for the FORM-A certificate, including the EU and Canada, Japan and other developed countries to China's GSP treatment, in the export of products can enjoy the normal rate (MFN rate) is lower tariff; FORM-E certificate mainly for the ASEAN Free Trade Area of the import and export trade in the enjoy preferential tariffs [14].

The General Administration of Customs has filed a record for all beneficiary countries, and the certificate of origin is valid for 180 days in accordance with the International General Rules. In addition, on the certificate of origin, it must have the issuing authority and the export of the customs seal. Sometimes, the parties will provide some certificate of origin not issued by the exporting country to avoid the high antidumping duties to the Customs and Excise Department. There are more diverse forms of "False evidence", apart from using the wrong format of the certificate, also including produce their own certificate of origin issued by the parties without permission, the parties fake the signature about responsible agencies, unauthorized modification some information about the product name and number about the certificate of origin. There are many such examples in the import and export trade, like white feather chicken origin false evidence in 2009 [15].

\section{The COUNTERMEASURES RESEARCH ON THE TRADE AND INVESTMENT FACILITATION OF GMS}

\section{A. Countermeasures study on tax revenue}

\section{1) International Law}

First, enhance the binding of documents. GMS member countries may achieve stronger legally binding documents on the tax on trade facilitation through progressive consultations and agreements in actual operation. The design of tax binding rules can be handled flexibly, broad framework principles can be formulated, the developing members can also be given certain flexibility in the way.

Second, learn from other international or regional trade multilateral measures. There are a number of international and regional organizations engaged in trade facilitation work. Like the "Kyoto Convention" signed by the World Customs Organization. Some principles have been put forward for standardization and simplification of Customs, which is based on the most advanced customs formalities, countries will put it as an example, it can not only improve the customs formalities and the facilitation of international trade, but also protect national law enforcement and implementation. In the GMS trade agreement, we should draw lessons from these systems and guide the member countries how to use them. We should combine the regional characteristics into the specific system so as to make the reference meaningful and effective [16].

Thirdly, it is recommended that the Ministry of Foreign Affairs and the Ministry of Commerce clean up the relevant agreements and then revise and supplement them according to the new situation in consultation with the countries concerned. At the same time, the Bilateral Economic and Trade Technical Cooperation Committee mechanism should actively operate and play a coordinating role. Our country should also sign with the sub-regional countries, customs cooperation, bank or monetary cooperation, agricultural cooperation and subregional cooperation to avoid double taxation of the necessary agreements.

\section{2) Domestic Law}

First, in the regulatory system, improve the supplementary trade and trade facilitation and foreign investment tax aspects of the relevant laws and regulations. The Chinese government has developed a large number of tax laws, regulations and policy measures in trade and investment, but the legal effect level is low and complicated. In order to ensure the systematic long-lasting and stable nature of these laws and regulations, the policy of the past characteristics of the pilot should be transformed into the foresee ability under the legal framework. We should draw on the mature laws and regulations in developed countries, summarize the experience in the past, use the effectiveness and regulation of the law to establish a promoting and protective tax law system about trade and investment, putting the existing policies and measures into the legal track, and further increasing the transparency, and than regulating the taxation of trade and investment.

Second, before or after the introduction of new laws and regulations, it should be refined, supporting the development of trade and investment tax-related laws and regulations. Including foreign exchange management, import and export customs clearance and so on.

Thirdly, under the framework of national laws and regulations, Yunnan and Guangxi province should formulate corresponding local laws, regulations and implementation rules according to the actual situation of economic and trade cooperation and development of themselves and sub-regional countries. In particular, we should pay attention to the actual tax problems and legal obstacles in the investigation and cooperation, and provide the first-hand situation and information for the construction of the national legal system in view of solving the practical problems in the process of cooperation and timely reflecting the relevant laws and regulations to the state. 


\section{B. Countermeasures study on inspection and quarantine} issues

\section{1) International Law}

Through the ongoing efforts of the sub-regional countries, signing multilateral multilateral agreements could resolve the problem. Specifically, in the case of product testing and certification standards and mutual recognition agreements with other countries in the sub-region, it is necessary to establish a unified cross-border product testing and certification standard and a cross-border logistics standard system as soon as possible. The implementation of international uniform product code, status code, to promote the standardization of goods and processes, to reduce transaction risk. At the same time, it also need to establish a unified logistics warehouse, freight yard, shelf specifications and construction standards, information system hardware configuration standards such as hardware standard system. For technical standards, the negotiations about technical barriers to trade should also start as soon as possible, to ensure that two sides can eliminate non-tariff barriers as soon as possible, to realize standardized, consistent coordination mechanism.

\section{2) Domestic Law}

In order to occupy a place in the sub-regional countries, we must pay attention to the consumer awareness to the brand, must provide high-quality products, adopting marketing techniques that conform to the national characteristics of subregional countries, cooperate with advertising and product trial, and it will be popular in sub-region. So, for goods exported to sub-regional countries, our country should make provisions in the form of administrative regulations, as follows:

First, the development of the corresponding administrative regulations, technical regulations to monitor the quality of export products, establish a good image of Chinese goods. In the domestic production links, the quality and technical supervision departments should be based on technical regulations to determine the product quality standards, in particular, with the national mandatory standards for its product quality supervision and inspection, the quality of the products are issued to the export of product quality Certificate of Conformity. At the same time, the administrative regulations should also stipulate that in the export sector, should be established with the export product quality certificate system with the relevant system, such as commodity inspection and quarantine, customs and other departments should develop appropriate quality management regulations to test whether the export of goods has obtained the national quality and technical supervision departments issued by the export product quality certificate.

Second, the state should make new adjustments to the current functions of the inspection and quarantine departments in the form of new administrative regulations. This is conducive to break the shackles of the interests of the sector, from the scientific and rational work needs, to avoid duplication of inspection, waste of financial budget, so that the national resources to be a reasonable allocation and improve the effectiveness of work and reduce the transaction costs of commercial entities.
Thirdly, when the Customs suspects the authenticity of the certificate of origin or the certificate of origin, the tax payment can be made at the agreed rate of the imported goods and the tax margin is levied at the difference between the MFN and the agreed tax rate according to different conditions, or the applicable tax rate, or refund the margin. With the gradual improvement of the law enforcement environment of China's customs, the awareness of law-abiding enterprises is increasing, and the measures taken by Chinese customs in counterfeiting should be more targeted.

\section{CONCLUSION}

GMS is the region's most important economic cooperation mechanism, its development reflects the economic cooperation and diplomatic interaction in surrounding countries. The development of the cooperative mechanism has gone through sprouting, progress and maturity, and every progress has included advocates - the Asian Development Bank and the efforts of the six countries. Economic activities require a legal system, GMS legal system is becoming more perfect, but there are many problems, such as lacking of investment special provisions, do not have their own independent dispute settlement mechanism. These all need together efforts to solve

As the core country in GMS, China naturally plays a leading role. In the daily cooperation, China should be positive to speak, to express views, and play an exemplary role for other countries. China should take the initiative to fulfill their obligations, bear the responsibility of a big country. To promote the development of GMS, China should actively participate in regional economic cooperation, encourage domestic enterprises and business to the region for trade and investment, improve administrative efficiency, simplify the approval procedures, and promote this cooperation mechanism to a better direction with the region's countries to achieve a win-win situation.

\section{ACKNOWLEDGMENT}

We would like to express our gratitude to all those who hel ped us during the writing of this thesis. Any progress that we have made is the result of their profound concern and selfless devotion. Particularly, we are greatly indebted to our tutor, Professor Zhang Honglie. Her willingness to give us her time so generously has been much appreciated. Truly, without her painstaking efforts in revising and polishing our drafts, the completion of this thesis would not have been possible. Finally, we will carry forward the academic spirit, apply the knowledge to our career in the future, and return all people who care about us and return society.

\section{REFERENCES}

[1] W.J. Lei. "Participating in the Cooperation of Trans Regional Highway Transportation Facilitation of GMS for Guangxi." Guangxi University, 2013

[2] P. Li, Y.X. Li and Y.X. Wang, "Achievements and Shortcomings of Yunnan in Promoting the Process of Trade and Investment Facilitation in the Sub-region," Yunnan Dynamic, 2005.

[3] "National Report on China's Participation in Greater Mekong Economic work," 2011. 
[4] Y.M. Bian."Review of the Legal System for Environmental Cooperation in the Greater Mekong Subregion," Forum on politics and law, 2010.

[5] M.D. Cao and S. Zhao, "Construction of Environmental Legal Mechanism in the Construction of China ASEAN Free Trade Area -Based on the Perspective of the Construction of International Environment and Resources Legal Mechanism in Regional Cooperation," Hebei Law, 2008.

[6] M. Li, "Legal Issues on Economic Cooperation in the Greater Mekong Subregion," University of International Business and Economics, 2007.

[7] "Greater Mekong River Trade and Investment Facilitation Strategic Action Framework".

[8] G.F. Zhu and L.D. Lin, "How To Avoid Double Taxation of Foreign Investment," Nanfang Daily.

[9] Z.W.Hong. "Laos's Participation in GMS Cooperation Issues," Northeast Normal University, 2014.

[10] Y.L. Yu, "Study on the Legal Mechanism of China ASEAN International Cooperation in River Protection," Chongqing University, 2011.

[11] X.S. Mou, Director of the General Administration of Customs in China: "There are three changes in the tariff system after China's accession to the WTO" People's Daily News.

[12] "China-ASEAN relations", Private economy newspaper.

[13] Y.Q. Zhu, "Legal Issues under the WTO Framework," East China Economic Management, 2003.

[14] X. Li, "The Problems and Countermeasures of China's Participation in the Economic Cooperation in the Greater Mekong Sub-region," SEZ economy, 2009
[15] L. Li, Q.C. Liu, "On the Origin of Regulatory Risk and Countermeasures of the Implementation of Anti-dumping Measures -the Thinking Caused by the Jianghan White Feather Chicken Origin False Cases," Jianghan Academic, 2016.

[16] X.Y. Li, "On the Lancang Mekong River Sub Regional Economic Cooperation Framework," Southwest University of Political Science and Law, 2008.

[17] M.Y. Yu, "Introduction to disputed settlement mechanism of WTO," Shanghai people's press, 2001

[18] "China's Participation in the Great Mekong River Economy Working Country Report," 2011.

[19] M.D. Li, "The Legal Regulation Problem of Greater Mekong Subregional Economic Cooperation,"Anhui University, 2010.

[20] Z.Y. Liu, "Study On trade Facilitation of GMS," Kunming University of Science and Technology, 2012.

[21] N. Ren and Y.J. Guo, "Cooperation Mechanism of GMS: Problems and Countermeasures," Strategic Decision Making, 2012.

[22] M.H. Shen, "Greater Mekong Sub Regional Economic Cooperation: the Complex Cooperation Mechanism and the Role of China," China ASEAN Yearbook, 2013.

[23] W.L. Wang," Legal Issues of GMS," Southwest University of Political Science and Law, 2013.

[24] J.X. Yang, "Analysis on Legal Mechanism of Environmental Cooperation in," Pacific Journal, 2009.

[25] Q. Yang, "Study On the Institutionalization of GMS," Modern Economic Information, 2012. 